\title{
Desenvolvimento e aplicação de uma torre de resfriamento no processo de fabricação de cachaças artesanais
}

Domingo Inácio de S. Neto'; Luís Gustavo Gontijo2; Tiago Portela Oliveira ${ }^{3}$; Mauro Luiz Begnini4. 1, 2, 3, 4 Universidade de Uberaba.

\section{domingos-isn@hotmail.com; gestor.engenhariaquimica@uniube.br}

\section{1 - Introdução}

O processo de produção da cachaça envolve várias etapas importantes, como moagem, filtração, sedimentação, fermentação, destilação, envelhecimento, envase e rotulagem, onde, em cada uma delas, há pontos críticos que podem ser decisivos para resultar em um produto de melhores qualidades intrínsecas e percebidas Um dos processos mais importantes na produção da cachaça é a destilação que separa os álcoois das impurezas presentes no mosto. Essa separação é feita através da adição de calor ao mosto, devido os álcoois possuir menor ponto de ebulição eles passam para o estado de vapor primeiro que as impurezas. Assim que este vapor alcoólico chega ao topo da coluna de destilação, ele é direcionado a serpentina onde faz a troca de calor com o metal por meio de contato e o mesmo repassa esse calor ao liquido refrigerante.

Em alambiques artesanais o líquido responsável por retirar essa carga térmica dos vapores alcoólicos geralmente são águas de rios próximos ao mesmo.

A utilização de águas de rios no resfriamento serpentinas de alambiques causa vários impactos ambientais como a alteração de $\mathrm{pH}$ do meio, aquecimento do efluente e contaminação por cobre.

A utilização de uma torre de resfriamento para substituir o uso de águas de rios para resfriar um processo industrial já vem sendo empregada em alguns processos. A água que sai da serpentina é alimentada e distribuída no topo da torre de resfriamento, constituída de um enchimento interno para melhor espalhar a água. $\mathrm{O}$ ar ambiente é insuflado através do enchimento, em contra corrente ou corrente cruzada com a água que desce. Por meio desse contato líquido gás, parte da água evapora e ocorre seu resfriamento (BORGES et. al,2009).

Numa torre de resfriamento, a principal contribuição para o resfriamento da água é dada pela evaporação de parte dessa água que recircula na torre. A evaporação da água - transferência de massa da fase líquida (água) para a fase gasosa (ar) - causa o abaixamento da temperatura da água que escoa ao longo da torre de resfriamento. Isso ocorre porque a água para evaporar precisa de calor latente, e esse calor é retirado da própria água que escoa pela torre. Vale lembrar que a transferência de massa da água para o ar ocorre porque as duas fases em contato tendem a entrar em equilíbrio. A evaporação de parte da água é responsável por aproximadamente $80 \%$ do resfriamento da água. A diferença de temperatura entre 0 ar e a água é responsável pelos outros $20 \%$ do resfriamento (CORTINOVIS; SONG, 2010).

O objetivo do presente trabalho foi desenvolver e aplicar uma torre de resfriamento ao processo de fabricação de cachaças artesanais.

\section{2 - Materiais e métodos}

A análise da influência do trocador de calor na temperatura da água de resfriamento e na eficiência do reator procedeu da seguinte forma. Aqueceu-se o reator com o reagente (mosto) até sua temperatura de trabalho que situa entre 80 e $90^{\circ} \mathrm{C}$, com a torre de resfriamento desligada efetuou-se a medição da temperatura do fluido refrigerante (água) na região inferior da torre e do fluido refrigerado (cachaça) com termômetro de mercúrio com escala de 50 a $200^{\circ} \mathrm{C}$ e também se mediu a temperatura da serpentina com um termômetro por infravermelho da marca RAYTEK, modelo MINITEMP. Após as primeiras medições ligou-se a circulação do fluido refrigerante (água) até que o mesmo entrasse em equilíbrio térmico com a serpentina, efetuaram-se posteriormente as mesmas medições realizadas com a circulação do fluido refrigerante parado. Assim que obtivemos todas as temperaturas 
8을 EnTec - Encontro de Tecnologia da UNIUBE / 28 a 30 de outubro de 2014

com o fluido refrigerante circulando ligamos a torre de resfriamento e repetimos todas as análises de temperaturas já realizadas.

Os materiais utilizados na produção foram:

- Panela de pressão convencional para o desenvolvimento da caldeira;

- Tubo de cobre de 1/4" para a ligação da caldeira a serpentina;

- Radiador de ar-quente de carro utilizado como serpentina;

- Vidro de espessura de $5 \mathrm{~mm}$ para a confecção da torre de resfriamento;

- Bomba submersa de aquário para a circulação de água na torre;

- Cooler de computador para a circulação de ar no interior da torre;

- Tubos de $1 / 2$ " para o transporte da água.

\section{3 - Resultados e discussão}

Após todas as medições efetuadas obtivemos os resultados que estão apresentados na tabela 1 - Dados obtidos da torre de resfriamento.

Tabela 1 - Dados obtidos da torre de resfriamento.

\begin{tabular}{|l|c|c|c|}
\hline & $\begin{array}{l}\text { Circulação } \\
\text { do fluido } \\
\text { refrigerante } \\
\text { e torre } \\
\text { desligada }\end{array}$ & $\begin{array}{l}\text { Apenas } \\
\text { circulação } \\
\text { do fluido } \\
\text { refrigerante } \\
\text { ligada }\end{array}$ & $\begin{array}{l}\text { Circulação } \\
\text { do fluido } \\
\text { refrigerante } \\
\text { e torre } \\
\text { ligada após } \\
\text { 15 min. }\end{array}$ \\
\hline $\begin{array}{l}\text { Temperatura } \\
\text { da } \\
\text { serpentina } \\
\text { (o-C) }\end{array}$ & 85 & 69 & 55 \\
\hline $\begin{array}{l}\text { Temperatura } \\
\text { do fluido } \\
\text { refrigerante } \\
\text { (o-C) }\end{array}$ & 32 & 65 & 39 \\
\hline $\begin{array}{l}\text { Temperatura } \\
\text { do fluido } \\
\text { refrigerado } \\
\text { (o-C) }\end{array}$ & 51 & & \\
\hline
\end{tabular}

Observou-se uma queda significativa de $35,3 \%$ na temperatura da serpentina quando comparada a primeira e a última análise. Isso implica diretamente no processo de destilação da cachaça já que os vapores alcoólicos aquecidos devem transferir calor ao meio (serpentina) para poder ser condensados e vir a geral o produto desejado (cachaça).

Inicialmente o fluido refrigerante estava à temperatura ambiente, pois não havia circulação e nem contato do mesmo com a serpentina já aquecida. Após a circulação do fluido refrigerante e contato do mesmo com a serpentina ele absorveu calor da serpentina até o ponto de equilíbrio térmico que foi quando efetuamos a segunda medição de temperatura. Ao ligarmos a torre de resfriamento houve uma queda brusca de temperatura caindo dos 65 para os $39^{\circ} \mathrm{C}$. Essa queda brusca de temperatura deve-se ao ar que entra pelas aberturas da torre com temperatura ambiente estar em contato com a névoa de fluido refrigerante e também pela evaporação de parte do mesmo.

No caso do fluido refrigerado (cachaça) obtivemos uma queda de $17,6 \%$ na temperatura da primeira para a segunda análise e de $7,1 \%$ da segunda para a terceira analise e também obtivemos uma queda de $23,5 \%$ quando comparada a primeira e terceira analise.

\section{4 - Considerações finais}

O objetivo do presente estudo foi alcançado com sucesso, pois obtivemos um ótimo resfriamento de todas as variáveis analisadas durante o estudo, com destaque para a temperatura da serpentina que mudou de $85^{\circ} \mathrm{C}$ para $55^{\circ} \mathrm{C}$.

\section{5 - Referências}

BORGES, André de Ávila. Mini-torre de resfriamento com ênfase a um trocador de calor do tipo serpentina. Tese de trabalho de conclusão de curso. Universidade Federal do Rio Grande do Sul, Porto Alegre, 2009. Disponível <http://143.54.70.55/medterm/20091/MINITORRE_DE_RESFRIAMENTO_20091.pdf>. Acesso em: ăbr., 2013.

CORTINOVIS, Giorgia Francine; SONG, TahWun.Funcionamento de uma torre de resfriamento de água. Revista de Graduacção de Engenharia Química. SI.,v. 6, n. 14 , jul.dez., 2005.2 Disponível em:<http://www.hottopos.com/regeq14/giorgia .pdf>. Acesso em: abr. 2013.

\section{Agradecimentos}

À Universidade de Uberaba pela realização das medidas ou empréstimo de equipamentos. 